УДК $551.435+551.417(268.45)$

DOI: $10.18524 / 2303-9914.2020 .2(37) .216562$

Yu. D. Shuisky, Professor, Doctor of Geogr. Sci.

G. V. Vykhovanets, Professor, Doctor of Geogr. Sci.

Department of Physical Geography, Nature Management and Geoinformation

Technology

Odessa I. I. Mechnikov National University,

Dvoryanskaya St., 2, Odessa, 65082, Ukraine

Physgeo_onu@ukr.net

\title{
ABOUT LITHODYNAMICAL PROCESSES ALONG THE KOLA FIORD COAST OF THE BARENTS SEA
}

This article is devoted to the study of the basic laws of the formation, structure, morphology and composition of sediments of accumulative landforms at the mouths of small rivers on the northern (fjord) coast of the Kola Peninsula washed by the Barents Sea waters. Along the northern Kola fjord Coast of Barentz Sea, the development peculiarities of lithodynamical processes are geographical location, expansion of old strong rocks with slowly rates of cliffs retreat and with severe hydrodynamical regime. As a result of this alongshore drift flows cannot develop. Normal exchange by sediment with adjoining regions of a sea shores are absent. Abrasive-denudation process is dominant, and it intensifies the sediment deficit within narrow coastal zone of the Sea. In addition, coastal deposition of the shore origin is unlikely along the entire distance by absolute Murmansk shoreline. The main reason is the strong impact of water dynamic and very steep shelf slope. They throw off sedimentary material to deep bottom without sphere of positive waves (surf) impulse for big debris of local rocks. That is why within the Northern coast of the Kola Peninsula the most important lithodynamical action all time were separate hearth's sites of deposition and short flows of migration. All time the fiord tops have location of sediment debris which undergo wave rubbing, and during sea-ice time discard shore sediment take place. A detailed analysis in the mouths of the Teriberka, Voronya and Kharlovka rivers where modern sandy terraces of the coastal-marine genesis lie have been carried out. It was noticed that the influenced of strong igneous and crystallized rocks and active physical weathering after the fast melting of snow from the catchment area carries away fine-grained material into the rivers (fractions $\leq 3 \mathrm{~mm}$ ). These materials which are composed mainly of Alluvials leads to the construction of terraces. The productive vector of the wind flow on the coast with an average long-term wind speed $\approx 8 \mathrm{~m} / \mathrm{s}$ is directed from land to sea. The smallest sediments are blown into the sea from the surface of the terraces. In contrast to the eastern shores of the Barents and White Seas, these sediments form sandy tidal dehydrations. Silt debris composed of fine-grained material of (fractions $\leq 1 \mathrm{~mm}$ ) dominates here. The main part of alluvium $\geq 1.0 \mathrm{~mm}$ is retained in river channels. It should be noted that on the studied coast, an average of $15.36 \%$ of these fractions erupt into the composition of coastal terraces. The smallest debris and part of the sand goes down to a depth along steep underwater slope (up to 
$\left.i_{10} \leq 0,15\right)$. On the frontal surface slope of the terraces, fractions of $1.0-0.25 \mathrm{~mm}$ on the beach dominate (of which the content is $0.5-1.0 \mathrm{~mm}=38.93 \%$ ). All sand fractions account for $88.78 \%$, including coastal dunes. The dune relief forms are small and are in the germinal state. They are characteristics of the mouths of the rivers where they exist.

Key words: Barentz Sea, shore, river mouth, sand terraces, estuaries, sea level, wind regime, fjords, sediment composition, aeolian forms.

\section{INTRODUCTION}

Over the past 2-3 decades, ideas about the coastal zones of the World Ocean as a single natural (physical-geographical) system at the active contact between the land and the Ocean have improved tremendously. Much focus has been laid only on the most important element of this system which is the mass of sediments of coastal-marine origin. Very little is known on how the system operates in itself as much as the exchange regime between the land and the Ocean. In the composition of the sea coasts, there are typical areas with abundant sediments which form numerous accumulative landforms. But those dominating in their composition have a distinct characteristic of their insignificant amount, like the case of fjord coasts [4-6]. On them, coastal accumulative forms are rare, they are small in size and are found in small numbers. In general, the accumulative forms do not have the characteristics of tectonic-glacial sea coasts. This is the reason why they have not been given adequate attention, by so doing they are less studied than forms of other origin.

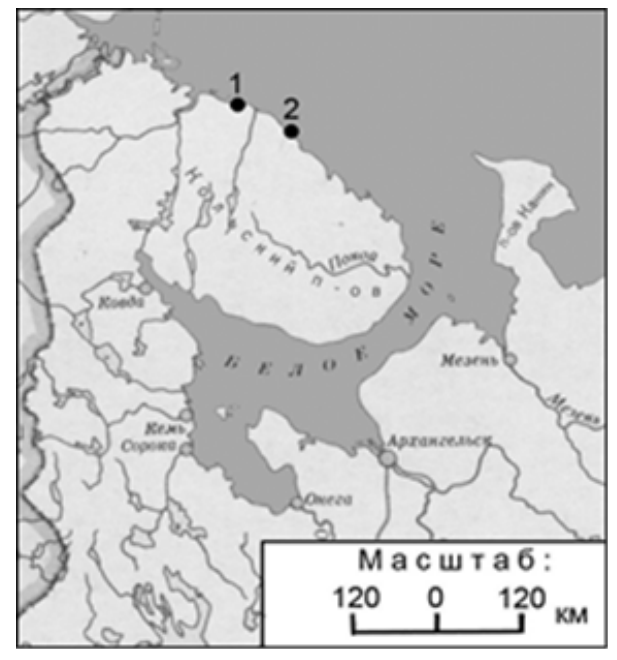

Fig. 1. Schematic map for the general location on Kola Peninsula along coast of the Barenz and White Seas.

Legend in the geography map. Black points: 1 - the Teriberka site of the investigation; 2 - the Voroniya site of the investigation
Based on the aforementioned observation, this article intends to carryout a special study on the characteristics of accumulative forms of coastal relief of the fjord coast of the Kola Arctic (Fig. 1), examine the general features of their dynamics and the composition of their sediments to ensure an optimal environmental management and better protection of their natural systems.

In order to achieve the stipulated goal of this article, the following main tasks are taking into consideration:

a) an analysis of the history of research on fjord coasts in the northern part of the Kola Peninsula;

b) the natural conditions for the formation of coastal accumulative landforms; 
c) the features of the morphology and dynamics of coastal landforms;

d) an analysis of sediments composing the accumulative forms of the coastal genesis.

These objectives will be examined and analyzed in greater details. The considered research results can be used to improve the theory of shore science and to justify the economic development of the fjord-type shores.

\section{RESEARCH METHODS AND MATERIALS}

This study made use of the standard methodology of coastal field survey which consists of data collection, data analysis and data interpretation. In September 2018, the XXVII International Coastal Conference held in Murmansk was attended by the authors of this article. As part of an out reach activity a scientific excursion was conducted at the Teriberka Bay (Fig. 2). During the tour, route studies of the

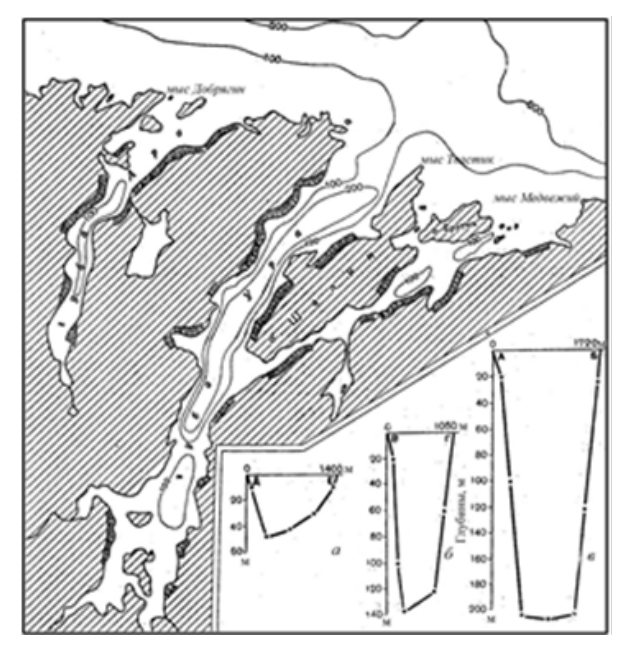

Fig. 2. Map-scheme of big fjords along Murman's coast of the Barentz Sea. Fragments $\boldsymbol{a}, \boldsymbol{b}$ and $\boldsymbol{c}$ are integral transversal profiles across of fjords: $\boldsymbol{a}$ and $\boldsymbol{b}$-Ara-guba fjord; $c$ Ura-guba fjord. Vertical axis is depth (meters); horizontal axis is width of fjord, in meters. Dark contour of the shore as a sites of abrasivedenudate cliffs (according by P. A. Kaplin [8]) terrace at the mouth of the Teriberka River were carried out. Sediment samples were taken along the transverse profile of the beach and at the beginning of the aeolian zone at characteristic points (near-shore strip, at the middle part of the beach, at the upper part of the beach, at the beginning of the Aeolian zone and at the Aeolian zone). In order to avoid random sampling, samples were duplicated at each point at a distance of $1 \mathrm{~m}$ from another. A total of 12 samples were taken. The analysis of the size of the particles was performed in the training laboratory of the Department of Physical Geography and Nature Management of Odessa I. I. Mechnikov National University (referred to as ONU) on 10 fractional screens which is traditionally acceptable in marine science $[6,16$, 18]. When scattering the fractions, the

weight ratios were determined by an SNUG II-300 (Jadever) electronic balance accurate to the third decimal place. The results from the analysis were analysis were presented in the form of cumulative curves, cumulative field curves, distribution curves, the median sediment diameter (Md), sorting coefficient (So), lead fraction (Co), etc. The sum total of sand fractions were equally calculated. V.A. Aprodov, MPD-1 microscope No. 64062-T was used to determine the degree of rounding of 
sediment grains. With the use of a microscope, the main light and heavy minerals in the fine sand fraction were determined. The length of the coastline, transverse profiles, slopes of the underwater and the tortuosity coefficient were calculated using a topographic map with a scale of 1: 100000. Space images from the Google Earth resource were used to determine the area of terraces and the change in time of the contour of their coastline. The hydrometeorological conditions were analyzed with data from the Murmansk and Teriberka weather stations [12]. Therefore, our work was carried out on a practical descriptive natural objective and performed according to the standard methodology of coastal field survey, with appropriate cameral and analytical processing.

In a nutshell the article made use of theoretical methods of synthesis and analysis, comparative geographical methods, cartographic and mathematical statistics. The authors equally made us of auxiliary data published in the works of other prominent coastal scientists in the likes of $[4-8,13-15,18,19]$. The data from their analysis was used to perform comparisons.

A brief history of coastal research. The materials published in scientific publications on the study of the coasts of the Barents Sea in the Kola Peninsula are very few. For instance, P.A. Kaplin [8] pointed that Murmansk fjords are small in total, but a several are bigger (Fig. 3).

This assertion was confirmed from the results of the XXVII International Scientific Conference convened by the working group of «Sea Shores» (RAS Council

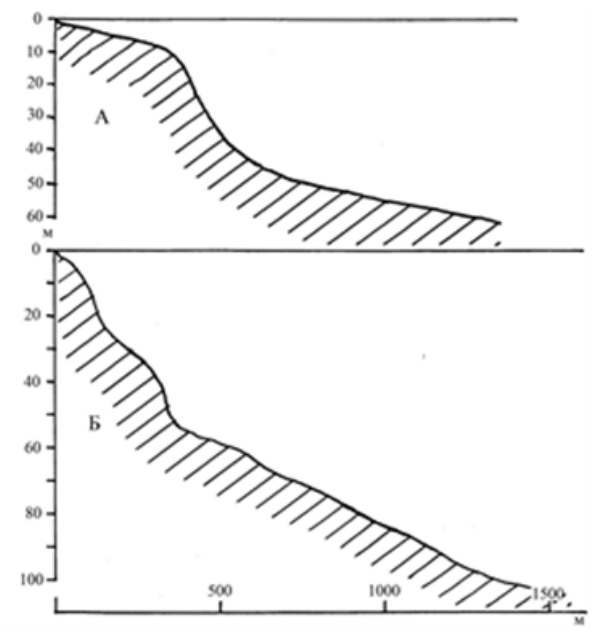

Fig. 3. Typical crossing profiles on submarine steep slope along Murman's fjord coast of the Barents Sea: $A$ - region of Voroniya open bay; $B$ - region of Teriberka open bay (estuary); 0 middle position of the sea level during period 1928-2017 years on World Ocean Problems) in Murmansk in autumn $2018[1,7,10]$. This conference summed up studies on the shores of the Arctic seas over the past two decades. From the more than 107 reports on the morphology and the dynamics of the coastal zones, only 3 reports were devoted to the study on the coasts of the Barents Sea in the Kola Peninsula. The most interesting report was [10], which is directly devoted to the process of abrasion on the shores of the Arctic seas, including the Barents. From his views [10], we argue that the cliffs of the Murmansk coast are characterized by minimal rates of abrasion which is exclusively influenced by abrasion-denudation factors. Several reasons can be responsible for this, which amongst others include. 
First, the northern part of the Kola Peninsula is composed of solid rocks belonging to class I in terms of the degree of resistance to abrasion [4, 18], which are easily yielded to wave destruction. They relate to slightly altered coasts of primary tectonics $[17,18]$. According to the conclusions of a number of prominent coastal scientists (Zenkovich V. P., Kaplin P. A., Suzdalsky O. V., Tarasov G. A., Medvedev V. S., etc.), these shores are fully explored. In addition to this view, it should be noted that for a long time the resources of the shelves, bowels and the ocean were intensively developed than those of the coastal territories. For this reason, research on geology and tectonic structure, general issues of oceanology of the adjacent waters were prioritized. Basically, the relief and composition of sediments on the seabed and biological resources were studied. Hydrocarbon prospecting and exploration was equally carried out, while information on the morpholithodynamics of the coast was of little demand.

Secondly, comprehensive and diverse studies were carried out only on the east of the Svyatoy Nos metro station, while the Kola coast of Murman and its modern lithodynamic objects and processes remained unstudied. Submarine and shelf slope is quite steeply, and sediment not accumulate along shores (Fig. 4).

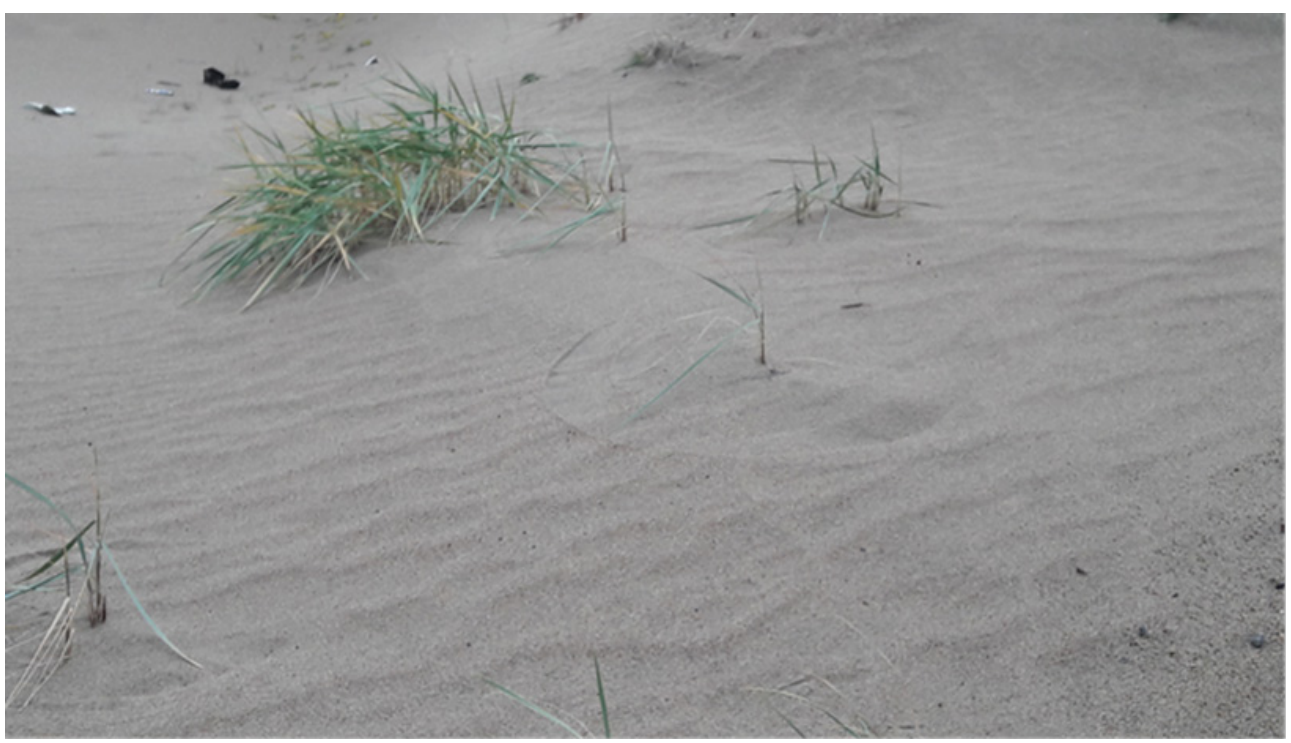

Fig. 4. Sandy ripple marks in surface of accumulative terrace in short Kharlovka fjord, when flow of strong winds intensive acting during autumn and spring

Thirdly, in foreign literature there is an opinion that there are few sediments on the fjord coast and, for this reason, accumulative forms of the coastal-marine genesis and related aeolian formations are absent everywhere $[1,15,17,21]$. By the way, coastal dune we meet not rare in the Arctic environment even.

Fourth, this coastal territory is poorly populated and inaccessible by land for 
coastal operations. The materials presented in this article at the moment are the first in the scientific literature devoted specially to the accumulative landforms and their eolian component on the Kola fjord coast of the Barents Sea (Fig. 4). Previous data related to their features were presented in the framework of studying the processes of sedimentation on the entire shelf of the southern part of the Barents Sea, as it was epitomized in the works of V. V. Alekseev and G. A. Tarasov.

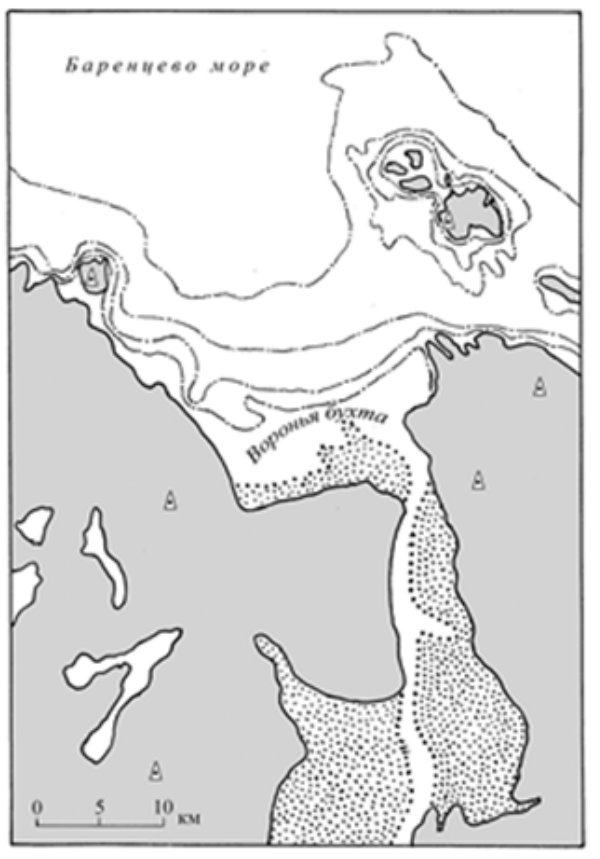

Fig. 5. Bay isobaths of Voroniya fjord within Kola coast of the Barentz Sea: close by shoreline isobaths $-20 \mathrm{~m}$ located; in the opened Sea direction isobaths $-50 \mathrm{~m},-100 \mathrm{~m},-150 \mathrm{~m}$ depth successive located. Points areas are sand tide flats in mouth of Voroniya river
Special interest have the relief forms and depth contours around nearest of every of fjord investigated coasts. As an example, we used marine aquathory nearest of Voroniya fjord and Voroniya estuary (Fig. 5). Presence of deep water in condition of tectonic fault scarp stipulated strong impact of stormy waves inside of the fjord, on sandy terraces inclusive. What is why lithodynamical process developing quite intensive on sandy terraces.

Taking into cognizance the fact that this coasts has been investigated by us today, as was earlier investigated by V. P. Zenkovich [4, 6] whom by 2020 would have turned 110 years old, we are highly delighted with due respect of the scientific order of valor to dedicate this article to the memory of V. P. Zenkovich (1910-1994), who is recognized in the World as the founder of modern coastal studies, who equally doubled as an active member of the VGO and the IGU.

\section{RESULTS AND THEIR DISCUSSION}

The General characteristics of terraces. Almost the entire northern coast of the Kola Peninsula is characterized by the absence of large accumulations of loose fragmentary rocks on the open sea coast and in estuaries. The absence of sediments is caused by the low rates of coastal abrasion, the increased strength of the hard rocks on

adjacent land, the steep slopes of the underwater on the tops of the fjords (lips, according to the local name), where rivers carrying sediments of different particle size distribution flow into it $[5,8]$. In the vast majority of fjords, the influence of large slopes of the coastal bottom sediments coming from river power sources are 
not deposited on it. They constantly slide to the foot of the underwater slope to great depths of up to 20-30 m or more. However, some bays such as Lodeynaya, Voronya, Klimovka lips and a number of smaller ones are an exception. Fig. 3 and Fig. 5 show that the underwater slope of these lips does not descends abruptly but stepwise to the foot to a depth of 100-200 m. As a result, relatively shallow sections of the bottom are formed at their peaks in the near-fore part favorable for the accumulation of large river sediments entering the coastal zone (Fig. 6).
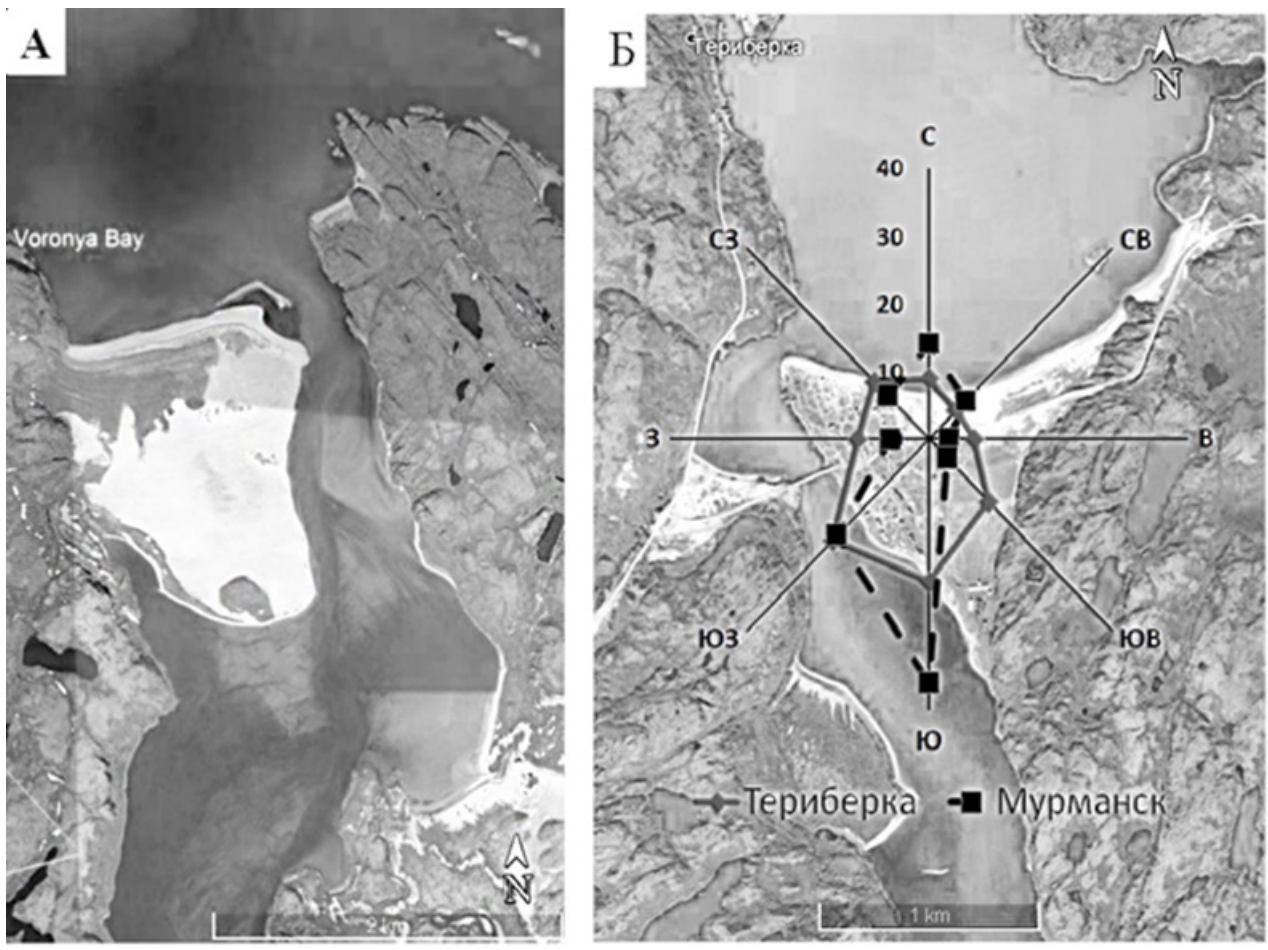

Fig. 6. Maps from the GOOGL resource for the northern fjord coast of the Kola Peninsula: A - Voronaya fjord; $B$ - Teriberka lip. Inside map B, superimposed wind roses according to long-term data at the Teriberka and Murmansk hydrometeorological stations

The beach drifts of different particle size distribution from the river channel under the influence of waves and wave currents undergo the process of coastal-marine differentiation divided into deposits of the wave $(\geq 0.1 \mathrm{~mm})$ and non-wave fields $(\leq$ $0.1 \mathrm{~mm})[5,17]$. Sediments of the wave field remain in the coastal zone and accumulate in the form of tidal drains, beaches and small terraces of the coastal/marine genesis. The size of these terraces is controlled not only by the slopes of the underwater, but also by the size of the solid river flow. The longer the river in length and the area of its catchment, the more sediment it carries, and the larger the mouth of the terrace will be formed, all other favorable environmental conditions of the coast was investigated. 
One of the major rivers of the Kola Peninsula is the Voronya River. It has a length of $210 \mathrm{~km}$, and a catchment area of $12,500 \mathrm{~km}^{2}$. One of the largest sand terraces on the northern coast of the Kola Peninsula is formed in its estuarine region with a surface area of $\mathrm{S}=2.1 \mathrm{~km}^{2}$. According its form, it is a monolithic sand body in the form of an irregular trapezoid on the left bank of the river (Fig. 5 and Fig. 7).

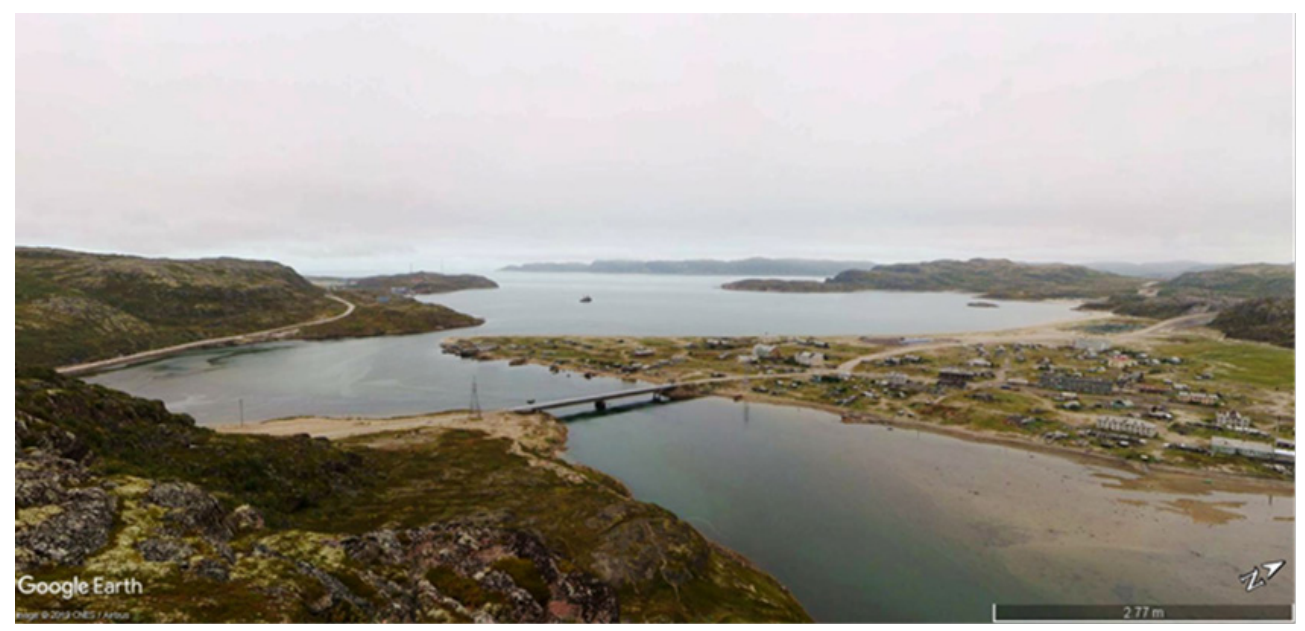

Fig. 7. Short fjord with twisting shoreline on northern coast of the Barents Sea. In central part of the picture fish settlement Teriberka is located

This bay formed the most favorable conditions for sediment accumulation in the coastal zone, at the direct confluence of the river into the Barents Sea. Along its entire sea edge, the slope of the underwater is moderately deep to a depth of $10 \mathrm{~m}$ and is on average 0.0270 . The length of the front coastline of the terrace is $1.23 \mathrm{~km}$. The contour of the coastline of the terrace is smooth and slightly concave arc. At the place where the river flows into the bay at the extreme eastern extremity of the terrace, an accumulative island is formed in the form of a young Month as a estuary. On satellite images of the Google Earth resource, an accumulative formation in the form of an island appeared in 2008. Since then, there were two accumulative protrusions on the site of the modern island extending from the coastline towards the sea. Most of the surface of the terrace is exposed. The vegetation in places is in the form of separate small foci among the surface of sand deposits.

Teriberka terrace was formed at the confluence of the Teriberka River in the bay Lodeinaya (local name of the fjord) (Fig. 7). The Teriberka River defers significantly from Voronya in terms of length and its catchment area . Its parameters in terms of catchment area and length are $2400 \mathrm{~km}^{2}$ and $120 \mathrm{~km}$, respectively. Such a difference in river sizes is reflected in terms of the area of terraces. Teriberka terrace is 1.43 times smaller than Voronya. In this respect it is an irregular quadrangle divided by the Teriberka River and a hill into three unequal sections (Fig. 6). The largest ( $\mathrm{S}=$ $0.94 \mathrm{~km}^{2}$ ) of them is located on the open right bank of the river in the form of an isosceles triangle. 
It fences the river valley from the top of the lip (fjord). The other two sections are much smaller. Their areas are $0.33 \mathrm{~km}^{2}$ and $0.16 \mathrm{~km}^{2}$ respectively. They are located in the concavity of the radical relief on the left bank of the river. The front outer coastline of the terrace is leveled, smoothly concave, stretching in a distance of 2.48 $\mathrm{km}$. The terrace is contoured by bare overgrown sands only along the edge, while the rest of the surface is covered with sparse grassy vegetation. The slope of the underwater lies to a depth of $10 \mathrm{~m}$. Along the entire front the Teriberka terrace is 3.7 times greater than Voronya and is on average 0.100 . With such underwater slopes, the conditions for sediment accumulation are less favorable than at the top of Voronya Bay. In other fjords of smaller size, sediment accumulations are even smaller and reach $0.08-0.16 \mathrm{~km}^{2}$, and not more than $0.3 \mathrm{~km}^{2}$.

On the transverse profile of the sea edge of the terrace and across the coastline, the following morphological elements are clearly traced from bottom to top: tidal dehydration, steep beach and aeolian zone. Sediment samples taken on each of them on the Teriberka Terrace showed that they were composed of well-sorted $\left(\mathrm{S}_{0}\right.$ $=1.15-1.60)$ sand grains $(\mathrm{Md}=0.30-0.75 \mathrm{~mm})$ mixed with gravel from $0,49 \%$ in the aeolian zone up to $29.02 \%$ in the near-fore. Near the terrace the surface is flat, in some places low (up to $0.5-1.0 \mathrm{~m}$ ) lonely aeolian hills and ridges rise. In some places it is covered with grassy and shrubby vegetation. Outside the zone of influence of tidal and forcing-surge waters, the projective cover of vegetation can reach $100 \%$, although most often it amounts to $40-60 \%$. The beach and part of the aeolian zone are characterized by partial or complete absence of vegetation. They are most often subject to periodic influence of tidal and storm waters, causing high mobility of the substrate (on which vegetation settles), which contributes to the destruction of plants. The vegetation cover destroyed by storms under tundra conditions is being restored very slowly. Surfaces of terraces, devoid of vegetation are immediately included in the scope of the wind flow.

Such a noticeable accumulation of sand material in the form of estuarine terraces is a potential source for the emergence and development of an aeolian relief. Most often it is absent. In general, its size is not commensurate with those that are found, for example, in the North and Baltic seas on the shores of the Bay of Biscay [2, 6, 18]. They are incomparably larger in the Baltic and on the Biscay coast. What are the reasons?

According to the theory of aeolian morphogenesis [2, 3, 22], the formation of the aeolian relief on the seashore depends on many natural factors. These includes the wind regime, the presence of an exposed surface of sediments, a variety of terrain, the length of the acceleration of the wind flow over an exposed sandy surface, the presence and parameters of the vegetation cover and the exposure of the accumulative form with respect to the dominant winds. Among the aforementioned factors, there are two main factors that can be distinguished. It should be noted that without these two factors aeolian morphogenesis is impossible to occur. These factors are:

a) the presence of loose sediments, mainly sand fractions; 
b) the wind regime (speed, repeatability of speed gradations and duration of the wind).

Everywhere in the world the main source of sediment on the seashore for the formation of the aeolian relief is the sea beach $[2,22]$. This is because during the unrest, new portions of sediment are constantly brought ashore by waves and wave currents from the underwater slope. The wind passing over the unprotected loose surface of the beach is saturated with sand material, and in places where its nanomotive force reduces, it deposits the sand which forms an aeolian relief (Fig. 8). The degree of saturation of the wind flow with sediment depends on the acceleration length on the area over which the wind accelerates. Experimental studies have shown that [2, 22] under ideal conditions on flat mono-sandy surface, the minimum length of wind dispersal is at least $10 \mathrm{~m}$ during strong winds. In the northern coast of the Black Sea under natural conditions this length can be 1.5-2.0 m more. This equally depends on the topography and humidity of the sand. On the studied terraces of Murman, the width and area of the beaches are sufficient to saturate the wind flow with sediment and move it over considerable distances.

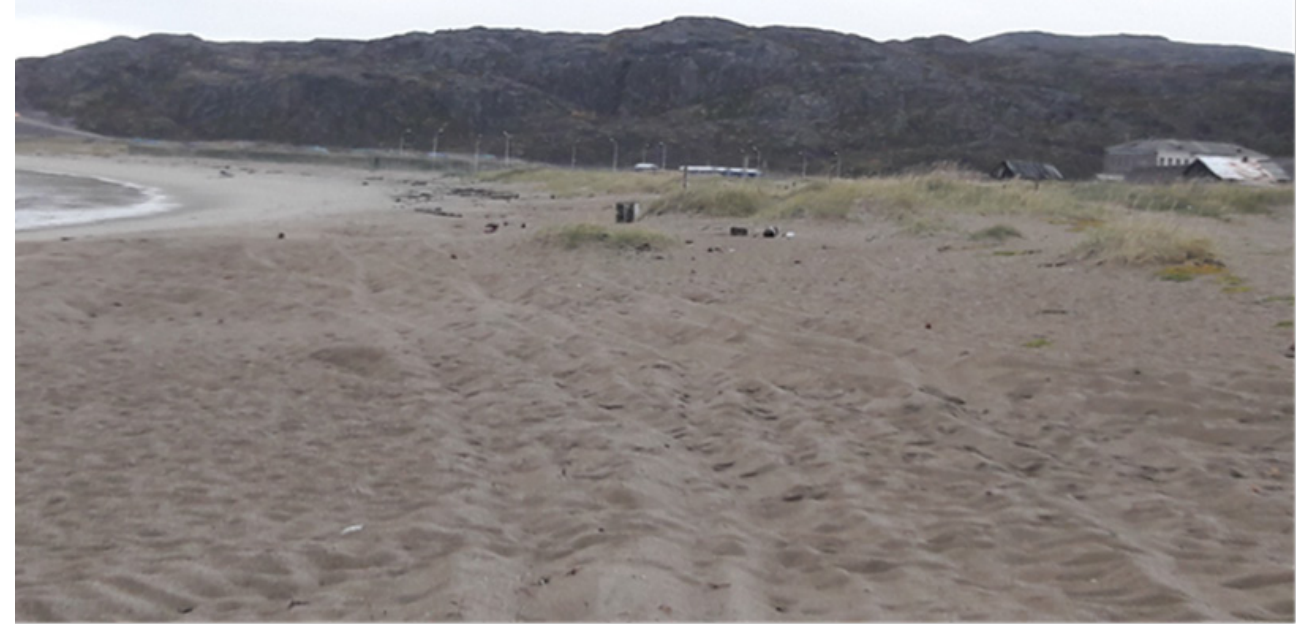

Fig. 8. Sand terrace in a top of big Kharlovka fjord with tide beach and small dunes, which covers original grass Spartina arctica, the view is after sea storm

The wind regime. This is important in the formation of wind-sand flow and in the formation of aeolian landforms. It is the driving force of aeolian morpholithogenesis both on the seashores and in the continent [2]. Wind parameters include (speed, duration, direction and repeatability). The wind direction with respect to the strike of the coastal line of the accumulative terrace is very important (Fig. 6 B). It often determines the formation of aeolian landforms on the seashore. Depending on the 
prevailing sediment transport along the strike of the coastline, certain conditions for the development of the aeolian relief need to be considered.

Firstly, if the wind and sand flow has a coastal component, the prevailing movement of sediment will be from the land. The leading process will be the blowing of sediments from the surface of the accumulative form into the sea. Under such conditions, the aeolian forms do not have sufficient time to adapt to the regime characteristics of the wind and have a small height of up to $1.0 \mathrm{~m}$.

Secondly, when the wind flow prevails from the sea, normal conditions (ceteris paribus), from the beach there is a constant supply of material to its dorsal and further to the coastal land. In this case, the formation of large forms of the aeolian relief of hilly and ridged type is possible. A glaring example is seen on the eastern and southern shores of the Baltic Sea.

Thirdly, very often the wind in all respects prevails along the accumulative form or close to this direction, which most often favors the formation of a large aeolian relief of the ridge type.

Having examined the importance of wind direction in the formation of aeolian relief, the performance characteristics of the wind has been analyzed with data from the weather stations of «Murmansk» and «Teriberka». In the studied Kola region of the Barents Sea, the wind regime is in accordance to the baric relief, with position at the centers of the Icelandic and Aleutian depressions, and the Siberian and Polar maxima $[9,12]$. On average in a year, the winds prevail from the southern side of the horizon. They account for about $60 \%$ in Murmansk, and 56\% in Teriberka (Fig. 6). The winds of the opposite northern points have a significantly lower frequency of $31 \%$ and $27 \%$ in Murmansk and Teriberka respectively. Across the year we noticed that in autumn fall and winter, westerly and southerly winds prevails, while in spring easterly prevails. In summer, the wind regime is unstable, and there is no clear prevalence of wind of a particular rumba. Almost all river valleys opening in the Barents Sea, including Teriberka and Voronya, have a meridional direction from south to north (). Therefore, on the studied terraces, the winds from the southern side of the horizon are coastal. They blow sediments from the surface of the terraces into the sea. On the contrary the winds from the north and east are marine. They transfer sediments from the sea beach to the surface of the terraces.

A universal indicator reflecting current trends in the development of aeolian processes is the coefficient of aeolian $\operatorname{drift}\left(\mathrm{K}_{\mathrm{eol}}=\mathrm{P}_{\mathrm{b}} / \mathrm{P}_{\mathrm{m}}\right)$. It represents the ratio of wind or aeolian movements from the coastal and marine sectors. On the Teriberka terrace, the coefficient is $2.07\left(\mathrm{~K}_{\text {eol }}=56 / 27\right)$. Such a value indicates that the surface of the terrace experiences a noticeably stronger influence of wind energy from the land side and at the same time, the role of aeolian drift on the sea beach and underwater slope increases due to the continuous deflation of the terrace surface. Despite the constant blowing of sediments into the sea from the terrace surface, aeolian forms in the form of separate low hills and their ridges of up to $1.0 \mathrm{~m}$ high are found in the upper part of the beach and the adjacent terrace. All varieties of aeolian relief are found from 
sand ripples (Fig. 4) to large hills and ridges. On the left western bank of the river the terrace is covered with hills from the effects of the winds of the southern rombuses. This is influenced by predominant winds from northern and north-eastern directions. They are 3.7 times likely to repeat than from the southern directions. Evidence from Figure 2 shows that in this part of the terrace the first quarter winds are marine. They supply sediments from the beach and the terrace surface to the foot-hills. Therefore, here, unlike the main part of the terrace, small aeolian hills and ridges elongated in the direction of the wind action formed in accordance with the wind regime, with a height of 1.5-2.0 m (Fig. 8). Such formations are rare, they are represented by the so-called leaning against the coastal dunes.

Another wind parameter of equal important is the wind speed. The degree of saturation of the wind flow with sediment depends on its speed. In general, it can be said that the greater the wind speed, the more sediment travels under favorable conditions. There are shear and moving wind speeds. On the seashore they are composed of fine and medium-grained sand. The shear velocity is $4.0 \mathrm{~m} / \mathrm{s}$ for dry sand in the surface horizon $(0.10 \mathrm{~m})$. At a speed of $4.5 \mathrm{~m} / \mathrm{s}$ there is a massive movement of sediment in the wind flow [3]. Such speeds on the surface horizon correspond to speeds at the height of the wind vane, equal to $7-8 \mathrm{~m} / \mathrm{s}$.

The wind regime of our study area is very severe (Fig. 5 and 6 B). The average annual wind speed at the Teriberka weather station is $7.1 \mathrm{~m} / \mathrm{s}$ [12]. Throughout the year (from October to April), the average monthly velocity is higher than the annual average which varies from $7.1 \mathrm{~m} / \mathrm{s}$ in April to $8.4 \mathrm{~m} / \mathrm{s}$ in December and January. Winds with moving speeds of $8 \mathrm{~m} / \mathrm{s}$ for sediments on the terrace blow 338 days on average over a long period. In the cold season from October to March, they are 1.77 times more likely (210 days) than in the warm period from April to September (118 days). The most severe wind regime is noticed by the end of autumn, winter and the first months of spring. In the same period of the year, the number of days with strong winds ( $\geq 15 \mathrm{~m} / \mathrm{s}$ ) capable of massively transporting sand and even gravel deposits in the wind and sand stream reaches 7.6-12.1 per month. In summer, strong winds are less frequent - only from 0.9 to 1.4 days in each month. The beginning of autumn is characterized by a greater number of days with strong winds (3.0-6.1), as compared to the mid and end of spring (2.3-4.5 days).

The repeatability of gradations of wind speeds is characterized by significant differences in directions. Winds with a speed of $\geq 10 \mathrm{~m} / \mathrm{s}$ have the greatest frequency of occurrence from the south and southwest points. They account for $2.0-1.9 \%$ of annual time, respectively, which is 2 times more in comparison with other areas. A comparison of the strong winds of the opposite coastal and sea magnetic bearing showed that the southern winds are 2.43 times more likely to blow compared to the north, and the southwest which blows 9.18 times more often than the north-east. Winds with a speed of $\geq 18 \mathrm{~m} / \mathrm{s}$ are possible only from the southern, western, northwestern and northern sectors of the horizon. Their repeatability varies from $0.002 \%$ in the southern and western magnetic bearing to $0.009 \%$ in the north-western and 
$0.025 \%$ in the northern magnetic bearing. From the above analysis it is evident that such high average annual and monthly average wind speeds are of great significance. This significance is based on the fact that almost throughout the year sediments are in motion and undergo a process of wind differentiation on the Teriberka and Voronaya terraces. The essence of the process is that in accordance with the wind speeds and directions, fine and medium-grained sediment fractions are blown from the terrace surface to the beach and the bay, and from the beach surface to the aeolian zone. The overwhelming dominance of the southern sector winds leads to the blowing of most sediment back into the sea. This implies that there was a confrontation which is an antagonistic relationship between the wave discharge of sediment ashore and wind drift into the sea. Due to the frequent freezing of desalinated waters at the tops of the Murmansk Fjords and the almost annual presence of the ice there, one of the authors [18] observed accumulation of coastal sediments of up to $10 \%$ of the ice mass. Long-term observations showed [17] that such ice drifts could reach up to 20 $\mathrm{t} / \mathrm{km}^{2}$, with fast ice power of up to $0.5 \mathrm{~m}$ during the frosty period.

Along with the wind characteristics, a significant influence on the movement of sediments and the power of the wind-sand flow is exerted by the humidity of sediments on the beach in particular and on the entire terrace surface in general. On most of the terrace in the exception of the beach, humidity depends on precipitation. In the Teriberka area for a year the average annual precipitation is $472 \mathrm{~mm}$ in the solid and liquid phases. From April to October $328 \mathrm{~mm}$ of precipitation was registered, which is 2.2 times more than the precipitation registered from November to March (149 $\mathrm{mm})$. This means that in the severe windy winter period and transitional seasons from autumn to winter and from winter to spring, the terrace surface is less moistened by precipitation. In addition, strong winds blows of moisture quickly from the surface, and negative temperatures in light snowy winters lead to its freezing in the upper horizons. Therefore, sand is most often dry and mobile under the influence of wind.

The composition of sediments and their distribution. Samples were took place along frontal sea side of different terraces and beaches. Basic its quantity located between ordinary of the Sea downhill and up to peak of aeolian ridge uphill of the every sand terrace in every fjord, that were investigated (Fig. 9 a). Laboratory working up shown forms of cumulative curves and field of curves. They are typical for conditions of Polar physical weathering and corresponding sedimentation under impact of tides and wind waves.

Sediment samples taken on a typical transverse profile of the beach and at the beginning of the aeolian zone of the Teriberka terrace showed that not more than 4 fractions are distinguished in their composition, but medium and coarse-grained sands prevail. All sand fractions taken together account for $77.92-89.8 \%$ at different points on the terraces. Against this background, the lowest content of sand fractions $(77.92 \%)$ was found in the near-boundary zone, from where they are washed out by the mud stream during a storm. In other areas, the content of these fractions is higher 


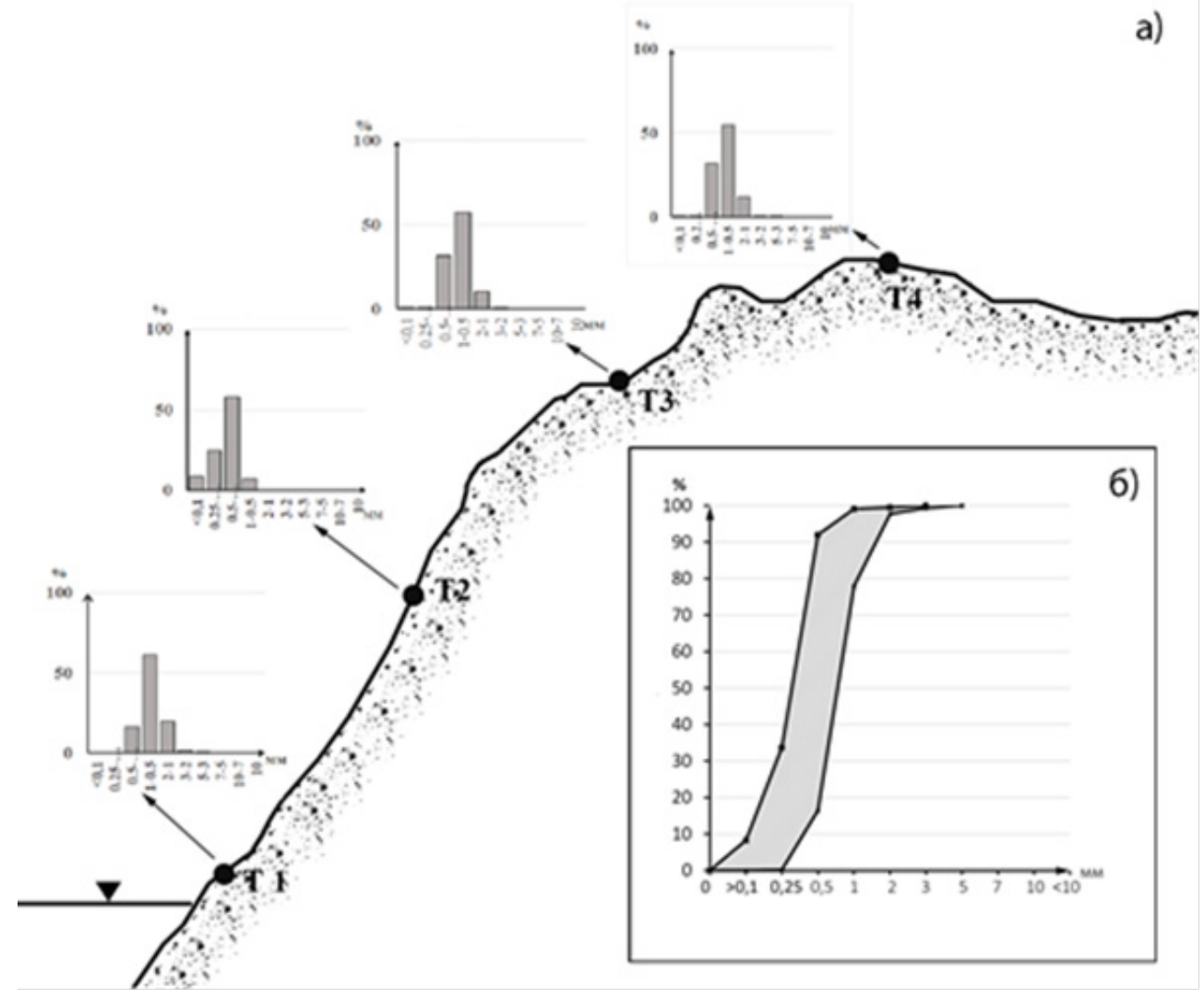

Fig. 9. Frontal sand slope profile (in average height are 5-7 m) with distribution of samples (T1-T4) in Teriberka sand terrace (a) and forms and fields of datum lines (b) after laboratory elaborations

and reaches $85.1-89.8 \%$. The median diameter of sediments varies from 0.3 in the middle part of the beach and the aeolian zone on the left bank to 0.75 in the nearshore zone. The upper part of the beach and the beginning of the aeolian zone of the terrace are characterized by transitional values of 0.60 .

The ratio of fractions showed that coarse sand predominates in the near-fore zone in the upper part of the beach and at the beginning of the aeolian zone. In the upper part of the beach and at the beginning of the aeolian zone, it is 1.52-1.94 times more than the medium-grained sand. Fractions of fine sand and silt-pelite are found in negligible amounts which accounts for $0.19-1.54 \%$. The increased content of coarse sand in the upper part of the beach and at the beginning of the aeolian zone is associated with the blowing of more mobile medium-grained and fine-grained sands by the prevailing winds of the southern quarter in the direction of the bay. Partly with strong gusts of wind, they fly across the entire beach and accumulate on tidal flats and underwater near-shore slope. Subsequently, during a storm small fractions are washed out from the near-shore belt and go to the underwater slope. With weak gusts 
of wind, some of the sediment reaches the middle part of the beach and is deposited there, in the zone of relative wind shadow. Therefore, in the middle part of the beach, the proportion of coarse sand decreases to $8.90 \%$, and the proportion of medium-grained, on the contrary, increases up to $58.6 \%$. Also, there is a high content of fine-grained sand, silt and silt-pelite size (30.24\%). At same time, we take attention on very narrow field of the datum lines (Fig. 9 b). It pointed on tightly conditions of sediment mobilization within the coastal zone of Barents Sea.

A similar ratio is observed in the aeolian zone on the left bank of the Teriberka River near the bridge (Fig. 7). This part of the terrace with the ledge of the hill is reliably covered from the south winds and is free from winds blowing from the bay. The most mobile medium and fine-grained sediments in the first place, as well as silt-pelite fractions move from the edge to the interior of the terrace under the influence of wind and accumulate there in the form of hilly and ridged sands. In this part of the sandy terrace, the content of coarse-grained sand is 3.83 times less than that of medium-grained sand, and the total content of fine-grained sand, silt and smaller particles reaches $34.18 \%$.

The sediment transport conditions and their deposition can be judged by the shape of the debris and the degree of their roundness. Assessment of the shape of the grains of sand and the degree of their roundness was carried out on five-point scale by considering and evaluating 100 particles from each sample, as recommended [16]. The result of our assessment showed that in all samples the sediments were rounded poorly. Mostly angular particles prevailed (0-1 roundness point). First of all, sediments are rounded in the sea part of the aeolian zone at the top of the beach, as well as on the terrace in site of the bridge. Here, the test result of 100 sand particles showed that small, very angular, and completely neo-rounded fragments with sharp cutting edges of ( $0-1$ point) predominate. The neo-rounded ( 0 points) accounted for $50 \%$ to $57 \%$, and those that completely retained their original shape and possess only slightly rounded (1 point) angles and ribs accounted for 33-37\%. Particles with slightly smoothed edges, in the outlines of which rectilinear segments are still clearly visible were noticed and accounted for $8 \%$ to $12 \%$ of cases. Almost all the smallest particles are neo-rounded. Such a low rounding point is due to the peculiarities of sediment movement in the wind-sand stream. Depending on the wind speed, the sand moves by rolling, drawing, saltation (jumping) and a long flight in the air stream. Fine sediment fractions are the most dynamic and are carried by a wide range of wind speeds. In the vast majority of cases, they are carried irregularly and in flight, that is repeated ups and downs on rocky and sandy surfaces are noted. This type of sediment movement causes frequent chipping of the edges of the sediment particles and the formation of sharp cutting surfaces. Large particles are more often moved by rolling. They often collide; rub against each other and with the underlying surface, which as a result leads to smoothening of the sharp corners. The near-shore part of the terrace is fed by sediments that are fed by waves from tidal dehydrations and fresh river material from the underwater slope, and then transferred by the wind to the central and coastal parts of the terrace. 
The deposits are rounded betters in the area near the beach. Here in the samples there are practically no particles (7\%) with sharp cutting edges, but the proportion of almost rounded particles of ( 3 points) reaches $22 \%$. The average round-off score turned out to be a little more than 2 . In the near-shore part of the beach, sediments are in constant motion along the coastal movement under the influence of waves and their surf flow. They often collide with each other, and the sharpest corners break off, sediment particles quickly roll around. They are also relatively well rounded in the middle of the beach. This part of the beach differs from the near-boundary zone in that there is less than $18 \%$ of the well-rounded particles and more than $18 \%$ of the content of debris with sharp cutting edges. This distribution of particles according to the degree of rounding is explained by the fact that sediments are fed into the middle part of the beach both in the surf during strong storms and in the wind and sand flow from the terrace surface. The upper part of the beach and the beginning of the aeolian belt which are affected by winds of all directions are composed of weakly rounded (0-1 point) sediments.

In the works of G. A. Tarasov and O. V. Suzdalsky [17], it is indicated that, in general, sediments of the coastal zone along the northern part of the Kola Peninsula have one mineral complex and can be attributed to a single mineralogical province. The main minerals in the light fraction are quartz, feldspate and plagioclases. The gross content of the heavy fraction are from $1 \%$ to $20 \%$ in different samples. Its composition is characterized of hornblende, epidote, pyroxenes, pomegranate, apatite, agyrin. Taking into account the particle size distribution, one can attribute the studied sediments to the group with slow mobility in the wave flow.

Having analyzed the distribution of sediments on the marine edge of the terrace and in the aeolian belt through the influence of the operating wind regime characteristics, we can state that several sections with different morpholithodynamic processes can be distinguished on each estuarine terrace. The middle part of the beach is characteristics of aeolian accumulation. It deposits sediment from both the surf zone and the wind-sand stream and from the terrace surface. The aeolian accumulation on the left bank of the river near the bridge is equally stable. It accumulates sediment coming from tidal drainage and moved by winds from the eastern side of the horizon. Wave bottom sediment separation is characteristics of the lower strip of the beach surf zone, and deflation prevails in the upper part of the beach and the beginning of the aeolian zone.

\section{CONCLUSIONS}

The Murmansk coast of the Kola Peninsula is the longest fjording shoreline in European Russia and with the largest number of small fjords. With regards to their length and depth they differ from a number of others on the coasts of Russia and the Scandinavia. However, they are not fully explored when compared with other fjord coasts.

Intense physical weathering of the surface of the Kola river watersheds and re- 
peated melting of heavy snow in winter led to the formation of large amount of sand in the river channels. Many factors have been responsible for the formation of estuarine sandy alluvial-deluvial terraces at the tops of the fjords. This includes the high intensity of wind waves on the adjacent sea, powerful wind-driven level fluctuations, the strong influence of tidal waves interaction with each other in the fjords and other components. The area of such terraces ranges from 0.08 to $2.20 \mathrm{~km}^{2}$, and the height above average sea level is up to 5-7 $\mathrm{m}$ of widths upper the sea-level.

The hardness of rocks in cliffs and on benches does not allow the abrasion process to be a significant source of coastal-marine sediments in the composition of sand estuaries. Therefore, the materials are mainly composed of alluvium as redeposited fragments from the physical weathering of hard rocks on the surface of local river catchments. The bulk of the sedimentary material in the terraces is represented by fractions from 0.25 to $1.0 \mathrm{~mm}$. Their total content is $77.2 \%$ on sea beaches and $88.78 \%$ on aeolian ridges. In general, the content of sediment grains larger than 1.0 $\mathrm{mm}$ is equal to only $\leq 15.36 \%$ in all terraces inside the fjords.

Most of the time from October to April, the average monthly wind speed is greater than shear and moving speeds for sediments that make up the terrace. During the year and on average over a long-term period, 2 or more integral prevalence of strong (shear and moving) winds from the southern side of the horizon was noted. The influence of meridional strike of the fjords from south to north has led to intensive sediment blowing from the surface of the terrace and the upper part of the beach to the underwater slope. As a result of this the aeolian relief forms do not have sufficient time to turn into more or less large ones.

\section{REFERENCES}

1. Bulavina, A. S. (2018), Istochniki antropogennoj nagruzki na pribrezhnye vody Barenceva morya [Sources of anthropogenic pressure on the coastal waters of the Barents Sea], Arkticheskie berega: put' $k$ ustojchivosti, Murmansk: Izd-vo MAGU, pp. 282 - 285 (in Russion).

2. Vykhovanec, G. V. (2003), E'olovyj process na morskom beregu [Aeolian process on the seashore], Odessa: Astroprint, 368 p. (in Russion).

3. Vykhovanec, G. V. (2004), Osnovnye polozheniya teorii e'olovogo morfogeneza na morskom beregu [The main provisions of the theory of aeolian morphogenesis on the seashore], Visnik Odes'kogo nacional'nogo universitetu. Geografichni ta geologichni nauki, Vol. 9. (4), pp. 129 144 (in Ukrainian).

4. Zenkovich, V. P. (1937), Nablyudeniya nad morskoj abraziej i fizicheskim vyvetrivaniem na Murmanskom beregu [Observations of marine abrasion and physical weathering on the Murmansk coast], Uchenye zapiski MGU. Geografiya, № 16, pp. 113 - 142 (in Russion).

5. Zenkovich V. P. (1938), Promyslovye karty gruntov gub Knyazh'ej, Voron'ej i Beloj [Commercial maps of soils of the Knyazhya, Voronya and Belaya lips ], Trudy VNIRO, Vol 5, pp. 32 - 43 (in Russion).

6. Zenkovich, V. P. (1962), Osnovy ucheniya o razvitii morskix beregov [Fundamentals of the doctrine of the development of sea coasts], Moskva: Izd-vo AN SSSR, 710 p. (in Russion).

7. Ivshin, V. A., Korsakov, A. L., Anciferov, M. Yu. (2018), Osobennosti sezonnoj dinamiki parametrov vod v vostochnom rukave guby Ura, Barencevo more [Features of the seasonal dynamics of water parameters in the eastern branch of the Ura Bay, the Barents Sea], Arkticheskie berega: put' k ustojchivosti, Murmansk: Izd-vo MAGU, pp. 231 - 235 (in Russion). 
8. Kaplin, P. A. (1962), Fiordovye poberezh'ya Sovetskogo Soyuza [Fiord coasts of the Soviet Union], Moskva: Izd-vo AN SSSR, 190 p. (in Russion).

9. Lappo, S. D. (1970), Prirodnye ledovye rajony okrainnyx arkticheskix morej [Natural ice regions of the Arctic marginal seas], Voprosy geografi, № 84, pp. 233-242 (in Russion).

10. Luk'yanova, S. A., Solov'eva, G. D. (2018), Abrazionnaya opasnost' na Arkticheskom poberezh'e Rossii [Abrasion hazard on the Russian Arctic coast], Arkticheskie berega: put' k , Murmansk: Izd-vo MAGU, pp. 246 - 250 (in Finnish).

11. Murmanskaya oblast': obshhegeograficheskaya karta / Masshtab 1:500000; 1:200000 (2017), [Murmansk region: general geographic map / Scale 1: 500000], Sankt-Peterburg: OOO ART-AT$L A S, 7$ p. (in Russion).

12. Nauchno-prikladnoj spravochnik po klimatu SSSR (1988), [Scientific and applied reference book on the climate of the USSR: Murmansk region], Issue 2, L.: Gidrometeoizdat, 314 pp. (in Russion).

13. Panov, D. G. (1937), Geomorfologicheskij obzor poberezhij Barenceva morya [Geomorphological survey of the Barents Sea coasts], Izvestiya Vsesoyuzn. Geografich. obshhestva, Vol. 69, № 6, pp. $522-534$ (in Russion).

14. Polkanov, A. A. Geologicheskij ocherk Kol'skogo poluostrova [Geological outline of the Kola Peninsula], Trudy Arkticheskogo instituta, Vol. 53. (in Russion).

15. Repkina, T. Yu. (2005), Morfolitodinamika poberezh'ya i shel'fa yugo-vostochnoj chasti Barenceva morya [Morpholitodynamics of the coast and shelf of the southeastern part of the Barents Sea], Extended abstract of candidate's thesis, Moscow: MGU im. M.V. Lomonosova, 24 3. (in Russion).

16. Ruxin, L. B. (1969), Osnovy litologii (Uchenie ob osadochnyx porodax) [Basics of lithology (the doctrine of sedimentary rocks], Leningrad: Nedra, 704 p. (in Russion).

17. Tarasov, G. A. (1982), Osadkonakoplenie na shel'fe yuzhnoj chasti Barenceva morya [Sedimentation on the shelf of the southern part of the Barents Sea], Extended abstract of candidate's thesis, Moscow.: GIN AN SSSR, 16 p. (in Russion).

18. Shuisky, Yu. D. (1986), Problemy issledovaniya nanosov v beregovoj zone morej [Problems of sediment research in the coastal zone of the seas], Leningrad: Gidrometeoizdat, 240 p. (in Russian).

19. Shuisky, Yu. D., Vykhovanec, G. V., , Gogoberidze G. G., (2020), Osobennosti pribrezhno-morskih akkumulativnyh form reliefa na Koliskom poberezhiya Barentseva morya [Features of coastal-marine accumulative landforms on the Kola coast of the Barents Sea], Izvestiya Russkogo Geograficheskogo obshchestva, Vol. 152 (2), pp. 31 - 42 (in Russian).

20. Aunan, K., Romstad, B. Strong (2008), Coasts and Vulnerable Communities: Potential Implications of Accelerated Sea-Level Rise for Norway. Journal of Coastal Research, Vol. 242, № 2, pp. $403-409$.

21. Doody, J. P. (1991), Sand dunes inventory of Europe. Peterborogh: JNCC Publ. Co., 81 p.

22. Horikawa K. (1988), Nearshore Dynamics and Coastal Processes. Tokyo: University of Tokyo Press, $522 \mathrm{p}$.

23. Rapp, A., Nyberg, R. (1988), Mass movements, nivation processes and climatic fluctuations in northern Scandinavian mountains. Norsk Geografisk Tidsskrift. Vol. 42, № 4, pp. 245 - 254 (in Norvegian).

\section{СПИСОК ВИКОРИСТАНОЇ ЛІТЕРАТУРИ}

1. Булавина А.С. Источники антропогенной нагрузки на прибрежные воды Баренцева моря [Текст] // Арктические берега: путь к устойчивости / Отв. ред. Е.А. Румянцева. - Мурманск: Изд-во МАГУ, 2018. - С. $282-285$.

2. Выхованец Г.В. Эоловый процесс на морском берегу. [Текст] - Одесса: Астропринт, 2003. $-368 \mathrm{c}$.

3. Выхованец Г.В. Основные положения теории эолового морфогенеза на морском берегу [Текст] // Вісник Одеського національного університету. Географічні та геологічні науки. - 
2004. - Т. 9. - Вип. 4. - С. 129 - 144.

4. Зенкович В.П. Наблюдения над морской абразией и физическим выветриванием на Мурманском берегу [Текст] // Ученые записки МГУ. География. - 1937. - № 16. - С. 113 - 142.

5. Зенкович В.П. Промысловые карты грунтов губ Княжьей, Вороньей и Белой [Мапи]// Труды ВНИРО. - 1938. - Том 5. - С. $32-43$.

6. Зенкович В.П. Основы учения о развитии морских берегов [Текст]. - Москва: Изд-во АН CCCP, 1962. $-710 \mathrm{c}$.

7. Ившин В.А., Корсаков А.Л., Анциферов М.Ю. Особенности сезонной динамики параметров вод в восточном рукаве губы Ура, Баренцево море [Текст] // Арктические берега: путь к устойчивости / Отв. ред. Е.А. Румянцева. - Мурманск: Изд-во МАГУ, 2018. - С. 231 - 235.

8. Каплин П.А. Фиордовые побережья Советского Союза [Текст]. - Москва: Изд-во АН СССР, 1962. - $190 \mathrm{c}$.

9. Лаппо С.Д. Природные ледовые районы окраинных арктических морей / [Текст] / Вопросы географии. - 1970. - № 84. - С. 233-242.

10. Лукьянова С.А., Соловьева Г.Д. Абразионная опасность на Арктическом побережье России [Текст] // берега: путь к устойчивости / Отв. ред. Е.А. Румянцева. - Мурманск: Изд-во Арктические МАГУ, 2018. - С. 246 - 250.

11. Мурманская область: общегеографическая карта / Масштаб 1:500000; 1:200000 [Мапи]. Санкт-Петербург: ООО АРТ-АТЛАС, 2017. - 7 с.

12. Научно-прикладной справочник по климату СССР. Выпуск 2: Мурманская область [Текст].Л.: Гидрометеоиздат, 1988. - 314 с.

13. Панов Д.Г. Геоморфологический обзор побережий Баренцева моря [Текст] // Известия Всесоюзн. Географич. общества. - 1937. - Т. 69. - № 6. - С. 522 - 534.

14. Полканов А.А. Геологический очерк Кольского полуострова [Текст] // Труды Арктического института. - 1936. - Том 53. - С. 85 -108.

15. Репкина Т.Ю. Морфолитодинамика побережья и шельфа юго-восточной части Баренцева моря [Текст] // Автореф. дис. на соиск. ученой степени кандидата географических наук. М.: МГУ им. М.В.Ломоносова, 2005. - 24 с.

16. Рухин Л.Б. Основы литологии (учение об осадочных породах) [Текст]. - Ленинград: Недра, 1969. - $704 \mathrm{c}$.

17. Тарасов Г.А. Осадконакопление на шельфе южной части Баренцева моря [Текст] // Автореф. дисс. на соиск. ученой степени кандидата геол.-мин. наук. - Москва: ГИН АН СССР, 1982. $-16 \mathrm{c}$.

18. Шуйский Ю.Д. Проблемы исследования наносов в береговой зоне морей [Текст]. - Ленинград: Гидрометеоиздат, 1986. - 240 с.

19. Шуйский Ю.Д., Выхованец Г.В., Гогоберидзе Г.Г. Особенности прибрежно-морских аккумулятивных форм рельефа на Кольском побережье Баренцева моря [Текст] // Известия Русского Географического общества. - 2020. - Том 152. - № 2. - С. 31 - 42.

20. Aunan, K., Romstad, B. Strong Coasts and Vulnerable Communities: Potential Implications of Accelerated Sea-Level Rise for Norway [Текст] // Journal of Coastal Research. - 2008. - Vol. 242. - № 2. - P. $403-409$.

21. Doody, J.P. Sand dunes inventory of Europe [Текст]. - Peterborogh: JNCC Publ. Co., 1991. - 81 p.

22. Horikawa K. Nearshore Dynamics and Coastal Processes [Текст]. - Tokyo: University of Tokyo Press, 1988. $-522 \mathrm{p}$.

23. Rapp, A., Nyberg, R. Mass movements, nivation processes and climatic fluctuations in northern Scandinavian mountains [Текст] // Norsk Geografisk Tidsskrift. - 1988. - Vol. 42. - № 4. - P. 245 -254 .

Надійшла 15.10 .2020 р. 
Ю. Д.Шуйський, доктор геогр. наук, професор

Г. В. Вихованець, доктор геогр. наук, професор

кафедра фізичної географії, природокористування і

геоінформаційних технологій,

Одеський національний університет імені I. I. Мечникова,

вул. Дворянська 2, Одеса, 65082, Україна

\title{
ПРО ЛІТОДИНАМІЧНІ ПРОЦЕСИ УЗДОВЖ ФЙОРДОВОГО КОЛЬСЬКОГО УЗБЕРЕЖЖЯ БАРЕНЦЕВОГО МОРЯ
}

\begin{abstract}
Резюме
В статті викладаються провідні закономіності розвитку літодинамічних процесів уздовж північного (фйордового) берега Кольського півострова на узбережжі Баренцевого моря. Навіть неозброєнним оком тут можна бачити суттєві відміни наносних форм прибережно-морського рельєфу, а відтак - незвичність всього літодинамічного процесу в береговій зоні. На жаль, ці відміни дуже мало вивчені як в країнах Азії, так і в країніх Європи, а в українській географічній та геологічній літературі вони майже невідомі. Тому для кращій обізнаності українських фахівців з питаннями прибережно-морських процесів взагалі ми взяли участь в міжнародній польовій експедиції за участю Фінляндії, Естонії, Туреччини, Куби та інших країн.

Особливостями розвитку літодинамічних процесів уздовж північного берега Кольського півострова є: а) географічне становище в межах особливої природної системи на півночі Європи; б) широке розповсюдження древніх скельних гірських порід на фланговій частині Балтійського щита, де берегова лінія заклалася на субширотній розколині, і виник незвично крутий підводний схил; в) незважаючи на крутий підводний схил і суворий хвильовий режим, наявність суттєвих припливів, процеси абразії $є$ послабленими, з вкрай невеликим скиданням наносів у берегову зону моря; г) підвищеною $є$ інтенсивність фізичного вивітрювання скельних гірських порід, а велика величина поверхневого стоку води веде до провідного джерела наносів алювіального, а не абразійного, як можна було б чекати. Берегова лінія звивиста, фйордові затоки вдаються до 2025 км углиб суходолу. Тому нема достатніх умов для розвитку вздовжберегових потоків наносів і широкого горизонтільного обміну наносами між суміжними ділянками. Домінування абразійно-денудаційних процесів посилює загальний дефіцит наносів у вузькій береговій зоні. До того ж виявилося нереальним накопичення прибережно-морських відкладів на всій довжині зовнішнього контуру берегу. Активний вплив сильних вітрових хвиль, припливів, синоптичних коливань рівня моря, надмірно крутий підводний схил ведутьдо того, що провідна маса відсепарованих крупних фракцій скидається униз по схилу під впливом прискорення вільного падіння та негативних хвильових імпульсів. Тому у вивчених фйордах Кольського півострова найважливими й найбільш типовими літодинамічними властивостями $€$ короткі горизонтальні міграції алювіальних наносів та їх накопичення у вигляді невеликих піщаних терас у вершинах фйордів. Ці утворення досягаються дією вітрових хвиль, відчувають переробку рельєфу, суттєвий вплив затирання часток наносів, а під час льодоставу - винос кригами у відкрите море.
\end{abstract}


Ключові слова: Баренцево море, берег, річкове гирло, піщана тераса, естуарій, вітрові хвилі, припливи, берегові дюни.

Ю. Д.Шуйский, доктор геогр. наук, профессор

Г. В. Выхованец, доктор геогр. наук, профессор

кафедра физической географии, природопользования и

геоинформационных технологий,

Одесский национальный университет имени И. И. Мечникова,

ул. Дворянская 2, Одесса, 65082, Украина

\section{О ЛИТОДИНАМИЧЕСКИХ ПРОЦЕССАХ ВДОЛЬ ФЙОРДОВОГО КОЛЬСКОГО ПОБЕРЕЖЬЯ БАРЕНЦЕВА МОРЯ}

\section{Резюме.}

В статье рассмотрены ведущие закономерности развития литодинамических процессов вдоль северного (фйордового) берега Кольского полуострова на побережье Баренцева моря. В результате экспедиционных исследований было выяснено, что особенностями развития литодинамических процессов вдоль северного берега Кольского полуострова являются: географическое положение в пределах особой природной системы на севере Европы; широкое распространение древних скальных горных пород на фланговой части Балтийского щита, где береговая линия была заложена на субширотной расщелине, и возник необычно крутой подводный склон; несмотря на крутой подводный склон и строгий волновой режим, наличие существенных притоков, процессы абразии является ослабленными, с крайне небольшим сбросом наносов в береговой зоне моря; повышенной является интенсивность физического выветривания скальных горных пород, а большая величина поверхностного стока воды ведет к ведущего источника наносов аллювиального, а не абразионного, как можно было бы ожидать. Береговая линия извилистая, фьорды залива прибегают к 20-25 км вглубь суши. Поэтому нет достаточных условий для развития вдольбереговых потоков наносов и широкого горизонтильного обмена наносами между смежными участками. Доминирование абразионно-денудационных процессов усиливает общий дефицит наносов в узкой береговой зоне. Активное воздействие сильных ветровых волн, приливов, синоптических колебаний уровня моря, чрезмерно крутой подводный склон ведут к тому, что ведущая масса отсепарированных крупных фракций сбрасывается вниз по склону под влиянием ускорения свободного падения и отрицательных волновых импульсов. Поэтому в изученных фьордах Кольского полуострова самыми важными и наиболее типичными литодинамическими свойствами являются короткие горизонтальные миграции аллювиальных наносов и их накопления в виде небольших песчаных террас в вершинах фьорда.

Ключевые слова: Баренцево море, берег, речное устье, песчаная терраса, эстуарий, ветровые волны, приливы, береговые дюны. 